\title{
Climate change and the occurrence of downy mildew in Brazilian grapevines
}

\author{
Francislene Angelotti(1), Emília Hamada (2), Edineide Elisa Magalhães ${ }^{(1)}$, \\ Raquel Ghini( ${ }^{(2)}$, Lucas da Ressureição Garrido ${ }^{(3)}$ and Mário José Pedro Júnior( ${ }^{(4)}$
}

\begin{abstract}
(1)Embrapa Semiárido, BR 428, Km 152, Zona Rural, Caixa Postal 23, CEP 56302-970 Petrolina, PE, Brazil. E-mail: francislene.angelotti@embrapa.br, edineide.fito@yahoo.com.br (2)Embrapa Meio Ambiente, Rodovia SP 340, Km 127,5, Tanquinho Velho, Caixa Postal 69, CEP 13820-000 Jaguariúna, SP, Brazil. E-mail: emilia.hamada@embrapa.br, raquel.ghini@embrapa.br (3)Embrapa Uva e Vinho, Rua Livramento, no 515, Caixa Postal 130, CEP 95701-008 Bento Gonçalves, RS, Brazil. E-mail: lucas.garrido@embrapa.br ${ }^{(4)}$ Instituto Agronômico, Avenida Barão de Itapura, no 1.481, CEP 13020-902 Campinas, SP, Brazil. E-mail: mpedro@iac.sp.gov.br
\end{abstract}

\begin{abstract}
The objective of this work was to evaluate the potential impact of climate change on the occurrence of grapevine downy mildew in Brazil. Seedlings containing four to six leaves were sprayed with a sporangia suspension containing $10^{5}$ sporangia per milliliter. After spraying, the seedlings were subjected to temperatures of $26,28,29.1,30.4$, and $31.8^{\circ} \mathrm{C}$ for 24 hours. The percentage of diseased leaf area and the latent period were evaluated. Maps of the geographic and temporal distribution of the disease were made considering the monthly average of the mean air temperature and leaf wetness duration for the reference climate or climate normal (1961-1990) and the future climates (2011-2040, 2041-2070, and 2071-2100), considering the A2 and B1 gas emission scenarios, designed by the Intergovernamental Panel on Climate Change (IPCC). Favorability ranges were set and used in logic functions of the geografical information system (GIS) to generate monthly maps for grapevine downy mildew. Rising temperatures interfered with the grapevine downy mildew infections, reduced the disease severity, and increased the latent period. Future climate scenarios indicate a reduction of favorability of downy mildew in Brazil, with variability in the different grape producing regions.
\end{abstract}

Index terms: Plasmopara viticola, Vitis, air temperature, geographical information system.

\section{Mudanças climáticas e ocorrência do míldio da videira no Brasil}

Resumo - O objetivo deste trabalho foi avaliar o potencial impacto das mudanças climáticas na ocorrência do míldio da videira no Brasil. Mudas com quatro a seis folhas foram pulverizadas com uma suspensão de esporângios de $10^{5}$ esporângios por mililitro. Após a pulverização, as mudas foram submetidas às temperaturas de $26,28,29,1,30,4$ e $31,8^{\circ} \mathrm{C}$, por 24 horas. Avaliaram-se a percentagem da área foliar doente e o período latente. Elaboraram-se mapas de distribuição geográfica e temporal da doença com as médias mensais da temperatura média do ar e da duração de período de molhamento foliar do clima de referência ou normal climatológica (1961-1990) e climas futuros (2011-2040, 2041-2070 e 2071-2100), nos cenários de emissão de gases B1 e A2, projetados pelo Painel Intergovernamental sobre Mudanças Climáticas (IPCC). Foram estabelecidas faixas de favorabilidade, utilizadas nas funções lógicas no sistema de informações geográficas (SIG) para a geração de mapas mensais para o míldio. O aumento da temperatura interferiu na infecção do míldio da videira, diminuiu a severidade da doença e aumentou o período latente. Os cenários climáticos futuros são indicativos de redução da favorabilidade do míldio no território brasileiro, com variabilidade para as diferentes regiões produtoras de uva.

Termos para indexação: Plasmopara viticola, Vitis, temperatura do ar, sistema de informações geográficas.

\section{Introduction}

The increase in the global average temperature in the last years has been a subject of great relevance for the scientific community due to the impacts caused in agriculture. Until the year of 2012, an increase of $0.85^{\circ} \mathrm{C}$ (Stocker et al., 2013) was observed, and the regionalized projections for Brazil are from 3.5 to $6.0^{\circ} \mathrm{C}$ of increase in air temperature and reductions in rainfall distribution until the end of the century (Ambrizzi \& Araújo, 2013). As the environment has a direct influence on the development of plant diseases (Ghini et al., 2012), the increase in temperature and changes in precipitation patterns may lead to significant changes in the occurrence and severity of diseases with direct impacts on food security (McElrone et al., 2010; Chakraborty \& Newton, 2011). 
Studies of the impacts of climatic change on the occurrence and the geographic and temporal distribution of pathogens have been carried out both through experimentation under controlled conditions and through projections using climate models that allow the climate and disease occurrence simulations (Pugliese et al., 2010; Shaw \& Osborne, 2011). The obtainment of experimental results allow the development and improvement of plant-pathogen coupled models, contributes to the evaluation of the effects of future climatic scenarios on the pathogen incidence and allows the elaboration of adaptation strategies (Ghini et al., 2012). The use of these models is based on physical principles, which describe characteristics of recent and past climate and, with considerable confidence, provide quantitative estimates of future climate change (Stocker et al., 2013).

The grapevine downy mildew, caused by Plasmopara viticola (Berk. \& Curt) Berl. \& de Toni, is a disease of great economic impact on different regions of the world. Temperatures between 20 and $25^{\circ} \mathrm{C}$ and leaf wetting are optimal conditions for the disease development (Caffi et al., 2016). In Brazil, the disease occurs in all states with grape cultivation and can cause losses of up to $100 \%$ of the production. Salinari et al. (2007) used simulation models and verified a potential advance in downy mildew outbreaks for the northern and southern hemispheres. However, the authors did not evaluate the producing regions of Brazil.

The objective of this work was to evaluate the potential impact of climate change on the occurrence of grapevine downy mildew in Brazil.

\section{Materials and Methods}

The study regarding the effect of temperature increases on grapevine downy mildew was conducted in the climate change laboratory of Embrapa Semiarido, in the municipality of Petrolina, in the state of Pernambuco, Brazil, in a growth room with temperature, humidity, and light control. In the evaluation of the effect of temperature increase caused by infection by $P$. viticola fungus, grape seedlings of Crimson Seedless, Thompson Seedless and Alicante Bouschet cultivars with four to six leaves were sprayed with a suspension of $10^{5}$ spores $\mathrm{mL}^{-1}+$ Tween 20 at $0.01 \%$. After spraying, the seedlings were submitted to temperatures of $26,28,29.1,30.4$, and $31.8^{\circ} \mathrm{C}$, and remained in a humid chamber for 24 hours. These temperatures were selected based on the additions of 2.0,3.1, 4.4, and $5.8^{\circ} \mathrm{C}$ on the mean temperature of the area of Submédio do Vale do São Francisco $\left(26^{\circ} \mathrm{C}\right)$, corresponding to the $\mathrm{B} 1, \mathrm{~B} 2, \mathrm{~A} 2$, and $\mathrm{A} 1 \mathrm{~F} 1$ future climate scenarios, respectively (Solomon et al., 2007). Subsequently, the seedlings were kept at a temperature of $26^{\circ} \mathrm{C}$ with a photoperiod of 12 hours until the onset of symptoms. To quantify the disease, the percentage of diseased leaf area with a diagrammatic scale was evaluated (Buffara et al., 2014). The latent period, determined by the number of days between $P$. viticola spraying and spore production, was also evaluated. The experiment was carried out in a randomized blocks design, with four replications per treatment.

In the preparation of the geographic database of climate information, the climatic variables of average air temperature, atmospheric pressure at sea level and specific air humidity were considered as a basis, which were made available in the Fourth Assessment Report (AR4) of the IPCC (Solomon et al., 2007). The information from these last two variables, plus the SRTM (Shuttle Radar Topography Mission) altitude data, were used to obtain the relative humidity, with the Tetens' formula (Tetens, 1930), due to the fact that this variable is not directly available in AR4. The duration of leaf wetness period (LWP) is one of the main factors for the occurrence of plant diseases. However, usually this climatic parameter is not systematically recorded in meteorological stations. Thus, one alternative would be to estimate this variable using mathematical models. Thus, LWP was estimated as a function of the relative humidity, with the method presented by Hamada et al. (2006).

The climatic variables effectively adopted for grapevine downy mildew were the monthly means of average air temperature and the LWP of the climate normal (1961-1990) and future climates (2011-2040, 2041-2070, and 2071-2100), in the scenarios of greenhouse gases emission, $\mathrm{B} 1$ and $\mathrm{A} 2$, from the IPCC. The B1 and A2 scenarios are called respectively "optimistic" and "pessimistic", and these scenarios were chosen due to the fact that they are extreme emission scenarios, so that with this evaluation of the possible impacts of climate change on the occurrence of plant diseases in the extreme scenarios, it would be possible to develop adaptive strategies with a higher safety margin. In the characterization of the climate normal, information obtained from the Climatic Research Unit (2016) was considered. The future 
climate was derived from the IPCC AR4 global climate model projections available at the Data Distribution Center (DDC) on the IPCC website (IPCC, 2016). In the characterization of the future climate, the arithmetic mean of the projections for 30 years, month to month, representative of the three studied periods, and the average of the models projections were calculated, considering seven models for atmospheric pressure at sea level and air specific humidity, for both scenarios, and 13 and 15 models for average air temperature, respectively, for the $\mathrm{B} 1$ and $\mathrm{A} 2$ scenarios. The number of models considered for the calculation of the arithmetic mean is different for each variable, since projected data of the climate variables are not equally available for all global climate models and gas emission scenarios. The models considered were those available, considering the South American continent.

The seven global climate models considered for atmospheric pressure at sea level and air specific humidity were: BCCR-BCM2.0 (from the Bjerknes Centre for Climate Research institution, Norway spatial resolution: $2.81252^{\circ} \times \sim 2.7904^{\circ}$ of latitude and longitude); CGCM3.1.T47 (Canadian Centre for Climate Modelling \& Analysis, Canada - resolution: $3.75^{\circ} \times \sim 3.711^{\circ}$ ), CNRM-CM3 (Météo-France, France - resolution: $2.81252^{\circ} \times \sim 2.7904^{\circ}$ ); GISSER (Goddard Institute for Space Shuttles, USA resolution: $5.0^{\circ} \times 4.0^{\circ}$ ); INM-CM3.0 (Institute for Numerical Mathematics, Russia - resolution: $5.0^{\circ} \times$ 4. $0^{\circ}$ ), MIROC3.2.medres (Center for Climate System Research, Japan - resolution: $\left.2.81252^{\circ} \times \sim 2.7904^{\circ}\right)$; and MRI-CGCM2.3.2 (Meteorological Research Institute, Japan - resolution: $2.81252^{\circ} \times \sim 2.7904^{\circ}$ ). For mean temperature data, 13 available models from B1 scenario were used, which were the same used for specific humidity, plus: CSIRO-Mk3.0 (CSIRO Atmospheric Research, Australia - resolution: $1.875^{\circ} \times 1.865^{\circ}$ ); ECHO-G (Meteorological Institute of the University of Bonn, Germany - resolution: $3.75^{\circ} \times \sim 3.711^{\circ}$ ), GFDLCM2.0 (US Dept. of Commerce/1 NOAA/Geophysical Fluid Dynamics Laboratory, USA - resolution: $2.5^{\circ} \times$ $2.0^{\circ}$ ), UKMO-HadCM3 (Hadley Centre for Climate Prediction and Research/Met Office, United Kingdom - resolution: $3.75^{\circ} \times 2.5^{\circ}$ ), ECHAM5 (Max Planck Institute for Meteorology, Germany - resolution: $1.875^{\circ} \times \sim 1.8652^{\circ}$ ), and CCSM3 (National Center for Atmospheric Research, USA - resolution: $1.40625^{\circ} \times$ $\sim 1.4007^{\circ}$ ); and 15 models of the A2 scenario, the same from B1 scenario, plus: UKMO-HadGEM1 (Hadley
Centre for Climate Prediction and Research/Met Office, United Kingdom - resolution: $1.875^{\circ} \times 1.25^{\circ}$ ) and PCM (National Center for Atmospheric Research, USA - resolution: $2.81252^{\circ} \times \sim 2.7904^{\circ}$ ).

The Geographic Information System (SIG-Idrisi 32) (GIS) was used for maps preparation. Due to the different spatial resolutions of the models provided by the IPCC, the data were submitted to interpolation methods, in order to have the final spatial resolution of $0.5^{\circ} \times 0.5^{\circ}$ of latitude and longitude. Then, the area corresponding to Brazil was picked up from the georeferenced data, and a mask with the states delimitation was applied on the maps.

Based on the information obtained experimentally, the mapping of grapevine downy mildew favorability was established with the following ranges: favorable, for LWP greater than 2 hours per day and average monthly temperature between 16 and $28^{\circ} \mathrm{C}$; less favorable, for temperature above $28^{\circ} \mathrm{C}$ and LWP higher than 2 hours per day; and unfavorable for LWP of less than 2 hours per day, regardless of the mean temperature - or for temperatures below $16^{\circ} \mathrm{C}$ and regardless of the LWP value. These criteria were used in the logical functions in GIS and in the production of monthly maps of favorability ranges for grapevine downy mildew. Monthly climate favorability maps for the occurrence of downy mildew for the climate normal were evaluated, and range intervals were adjusted until they were validated by professionals from Embrapa and Instituto Agronômico de Campinas, based on the occurrence of the disease in the different producing regions of the country. Then, the same criteria were adopted in the preparation of future climate maps.

\section{Results and Discussion}

In the evaluation of the effects of temperature increases on grapevine downy mildew, a latent period of five days was observed in the seedlings maintained at $26^{\circ} \mathrm{C}$ for the three evaluated cultivars (Figure 1). The highest latent period was nine days in seedlings maintained at $31.8^{\circ} \mathrm{C}$. The seedlings submitted to $33^{\circ} \mathrm{C}$ showed no symptoms of the disease. Temperature can determine the speed and extent of infection. Thus, the temperature increase delayed the appearance of the grapevine downy mildew in seedlings of the analyzed cultivars. According to Rossi et al. (2008), in the field, an increase in the number of days between infection and sporangium production may reduce the rate of disease progression. 
The severity of grapevine downy mildew decreased with an increase on temperature, with the highest levels of infection occurring at $26^{\circ} \mathrm{C}$ and the lowest at $31.8^{\circ} \mathrm{C}$ (Figure 1). Among the climatic factors, temperature and leaf wetness are the main determinants in the infection process of grapevine downy mildew. Vine leaves become infected at temperatures of 12 to $28^{\circ} \mathrm{C}$ in the presence of free water in the leaves (Lalancette et al., 1988). However, the present study observed the occurrence of downy mildew in plants submitted to a temperature of $31.8^{\circ} \mathrm{C}$. Schmidt et al. (2012), when studying the pathogenicity mechanisms of $P$. viticola, observed that sporangia tolerate dehydration at $37^{\circ} \mathrm{C}$, without loss of pathogenicity. However, Kennelly et al. (2007) observed a reduction in sporulation of lesions on days with high temperatures, reaching $42.8^{\circ} \mathrm{C}$.

These results were used for the definition of the ranges of climatic favorability to the occurrence of the disease, in the elaboration of maps of geographical distribution, for Brazil, regarding the future climatic scenarios. Thus, the geographic and temporal distribution maps of grapevine downy mildew for the future climate indicated a reduction in environmental favorability to the occurrence of grapevine downy mildew in relation to the climate normal (1961-1990) (Figures 2, 3, and 4). These results were confirmed by the experiment in a growth room, in which it was observed that the increase in temperature leads to a reduction in the progression of the grapevine downy mildew incidence (Figure 1).

Currently, the potential risk of occurrence of grapevine downy mildew is concentrated in the months of January to July, for the Northeast Region of Brazil; and from October to May, for the South and Southeast Regions of Brazil (Figures 2, 3, and 4). For the annual average, the area favoring the occurrence of grapevine downy mildew in Brazil is around $90 \%$, with $1 \%$ of less favorable area and $5 \%$ of unfavorable area (Figure 5). In B1 scenario, for the period 20712100 , the favorable area will decrease to approximately $43 \%$, the less favorable area will increase to $48 \%$, and the unfavorable area will increase to $8 \%$. For the A2 future scenario, in the period between 2071 and 2100 , increases of $10 \%$ of the unfavorable area and $70 \%$ of the less favorable area were estimated, as well as $20 \%$ of reduction in the favorable area, with predominance of less favorable areas to the occurrence of the grapevine downy mildew (Figure 5).
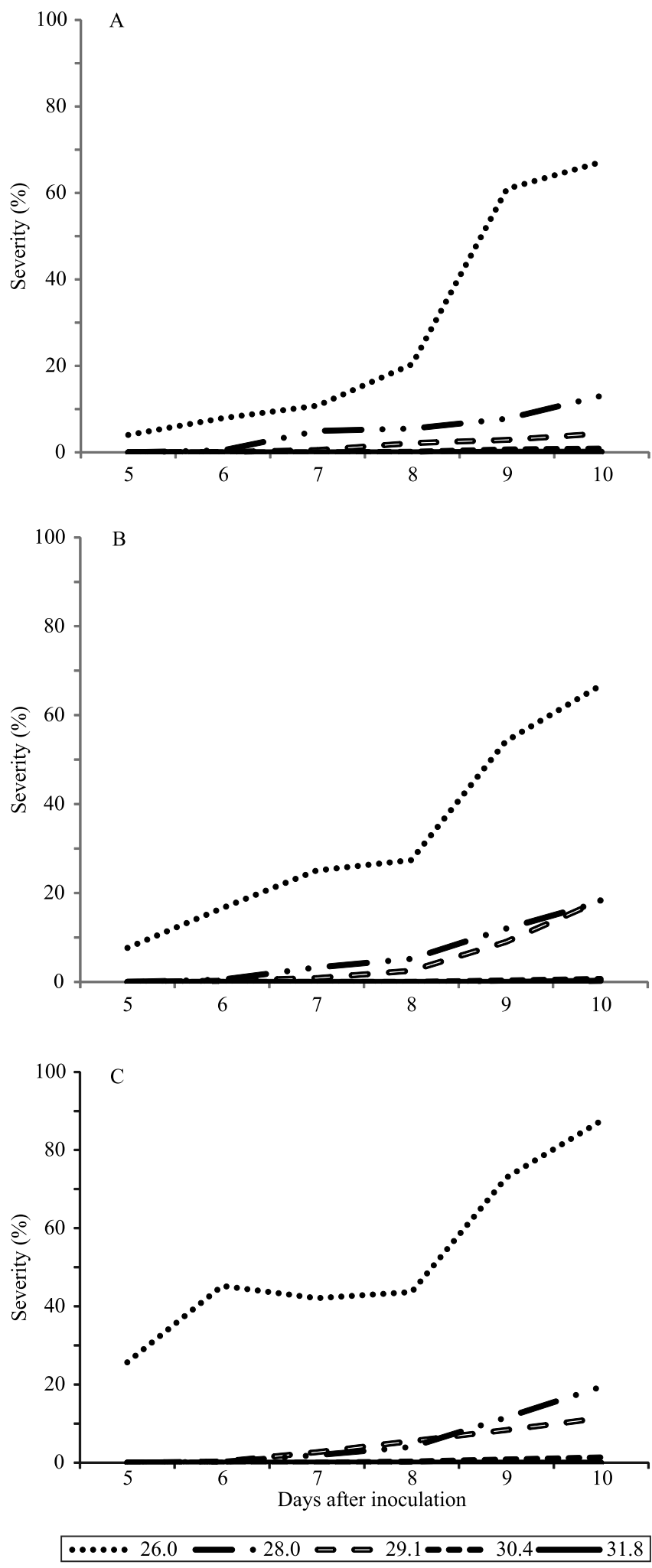

Figure 1. Grapevine downy mildew (Plasmopara viticola) progress according to days after inoculation and temperatures for the cultivars Thompson Seedless (A), Crimson Seedless (B), and Alicante Bouschet (C). 


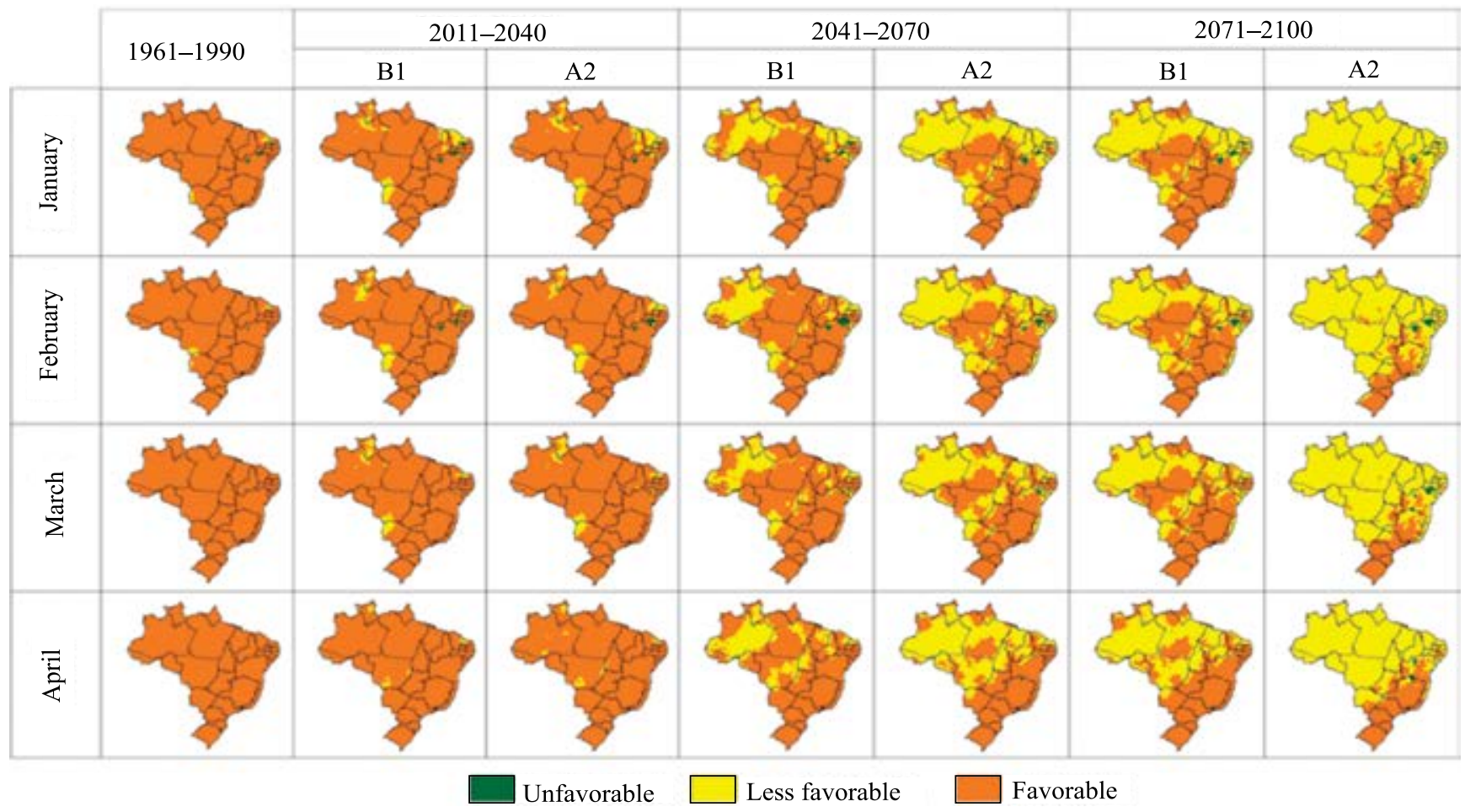

Figure 2. Climatic favorability for the grapevine downy mildew (Plasmopara viticola) in Brazil from January to April for the climate normal (1961-1990) and future climates (2011-2040, 2041-2070, and 2071-2100) in the B1 and A2 scenarios.

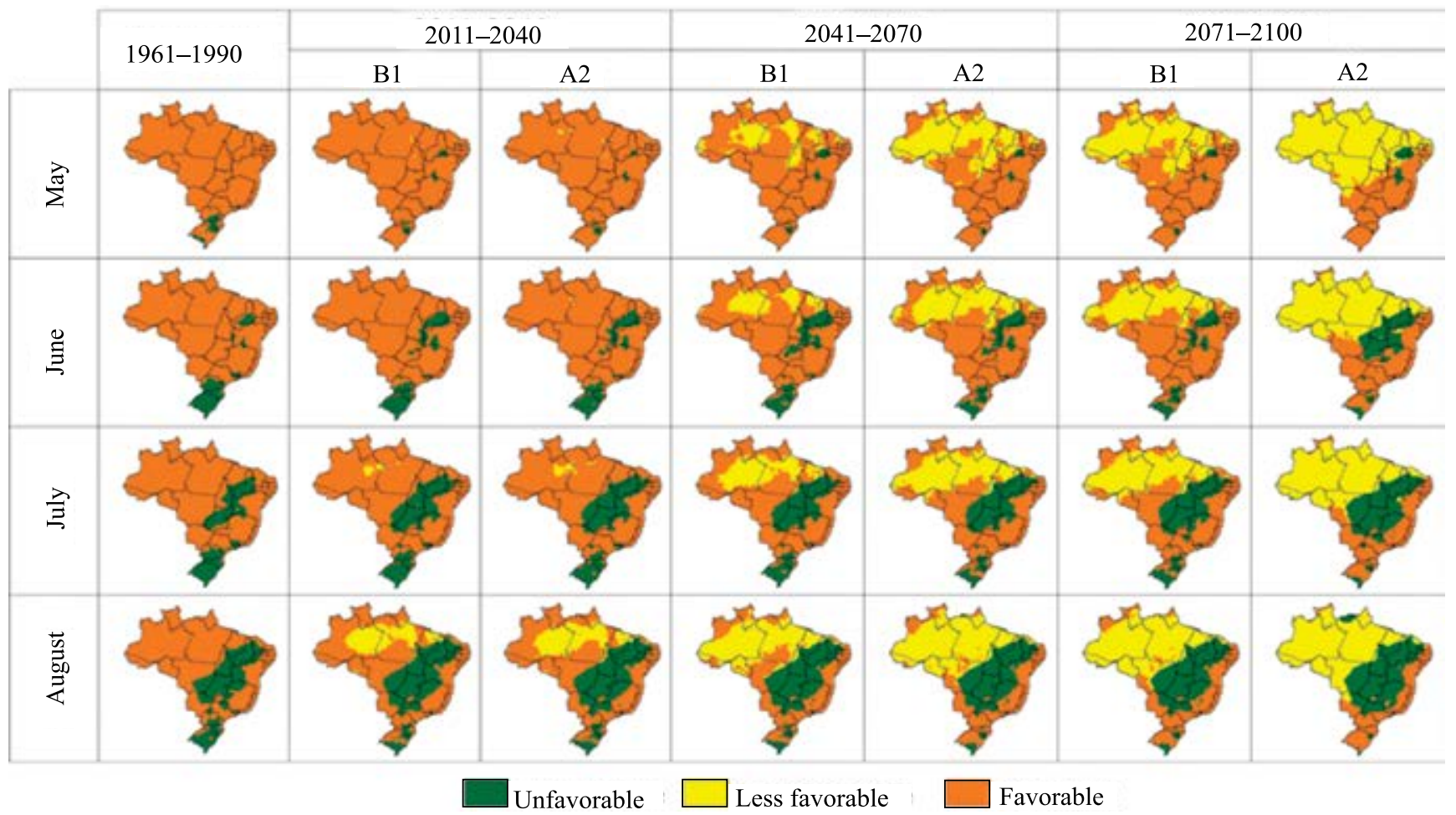

Figure 3. Climatic favorability for the grapevine downy mildew (Plasmopara viticola) in Brazil from May to August for the climate normal (1961-1990) and future climates (2011-2040, 2041-2070, and 2071-2100) in the B1 and A2 scenarios. 
For the Southern Region of Brazil, in the latitudes above $23^{\circ} \mathrm{S}$, vine has the winter interval, a period without production, resulting from the low temperatures in the months of June to August. Pruning is usually performed in August, and the first shoots appear in September with rising temperatures. In general, the incidence of downy mildew incidence is observed from October to December (first phase), and late outbreaks (second phase) can be observed in the months of January to March. Regarding the B1 and A2 scenarios, it is possible to observe an increase in the temperature for this region in August, with consequences such as the anticipation of pruning for July and greater exposure of the host plant to the grapevine downy mildew outbreaks from September to December; and as a consequence, the period of greatest favorability to the disease will be extended, leading to an increase in financial spending on pathogen control. In the north of the state of Paraná, the most critical periods for downy mildew occurrence are from November to February and from July to September - the last period coincides with the budding and flowering phase of the crop. During these periods, no changes that could favor downy mildew occurrence were observed. In eastern state of São Paulo, the period of greatest vulnerability of the crop occurs in the period of October to December, and in the municipality of Jales, in the state of São Paulo, from April to July. For these areas, favorability to the disease remained unchanged, except for Jales, where there was a reduction of favorability for July, when the A2 scenario is considered. In Submédio do Vale do São Francisco, the occurrence of downy mildew with potential impacts occurs from March to June, which coincides with the rainy season. As, in this region, sprouting may occur throughout the whole year, it was possible to verify the reduction of the favorable area in the period of December to May, due to the increase in temperature and reduction in precipitation. In relation to the Semiárido (the semiarid region of Brazil), the climate projections showed signs of temperature increase between 3.5 and $4.5^{\circ} \mathrm{C}$, and a 40 to $50 \%$ reduction in rainfall distribution (Ambrizzi \& Araújo, 2013).

In contrast to the results obtained in Brazil, it was verified that the grapevine downy mildew may cause negative impacts in Italy, South Africa, Chile, and

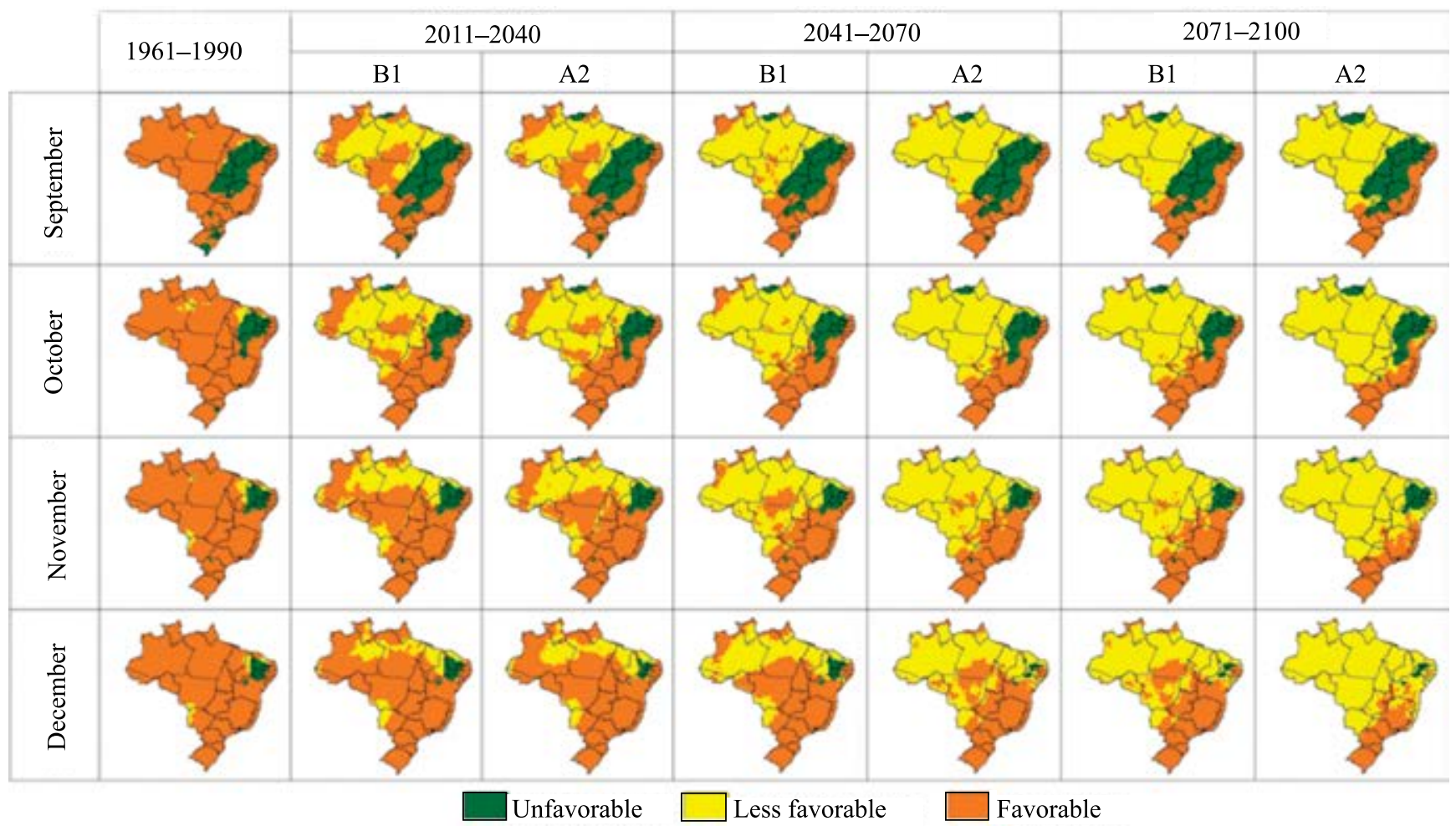

Figure 4. Climatic favorability for the grapevine downy mildew (Plasmopara viticola) in Brazil from September to December for the climate normal (1961-1990) and future climates (2011-2040, 2041-2070, and 2071-2100) in the B1 and A2 scenarios. 
China (Salinari et al., 2006, 2007). In these countries, epidemics are caused by primary infection, in which an increase in air temperature may accelerate oospore germination (Rossi et al., 2008). With these results, it can be inferred that there will be an increase in the production cost of the grapevine, due to the need for changes in the schedule and the number of fungicide applications (Salinari et al., 2006, 2007).

Regarding the percentage of the favorability classes of grapevine downy mildew according to the seasons of the year (Figure 6), an increase in the less favorable area was observed for summer, autumn, winter, and spring, with a consequent reduction in the favorable
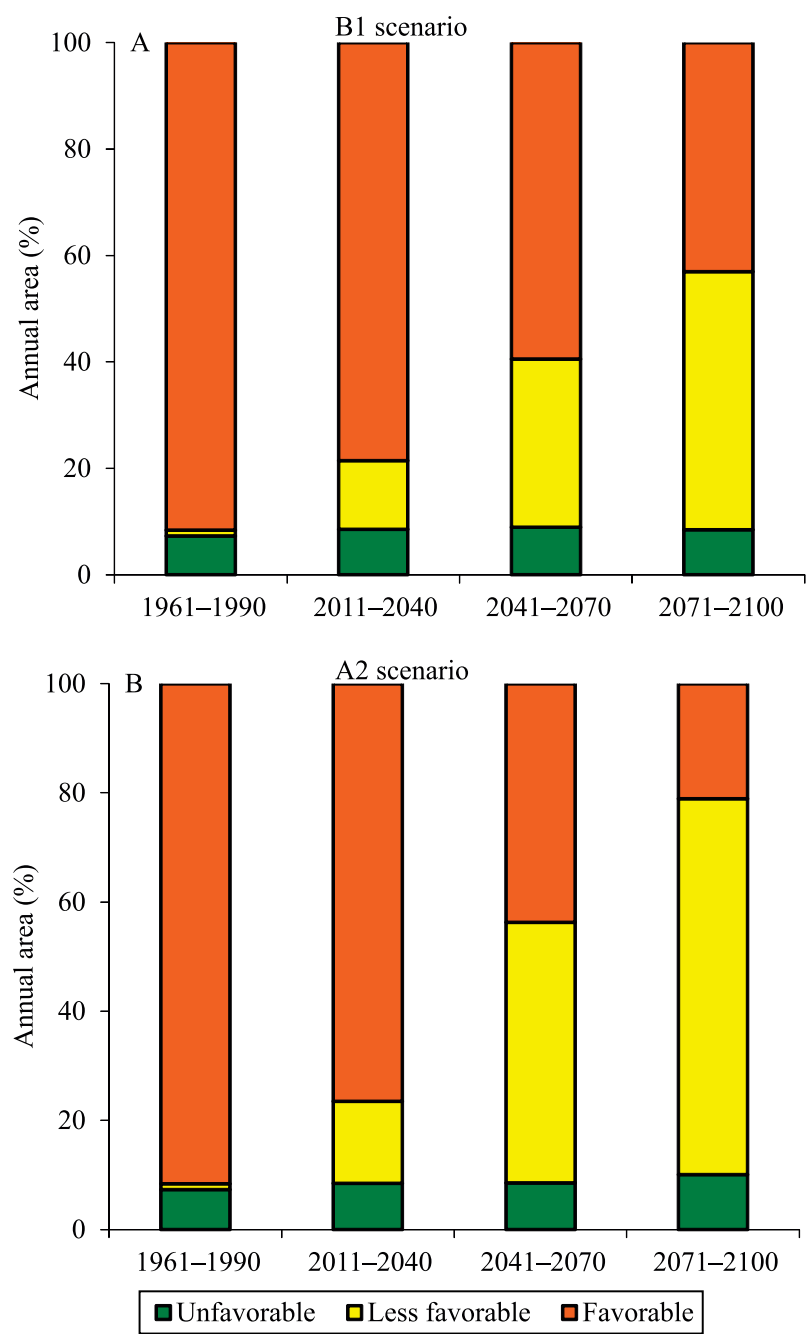

Figure 5. Means for annual area of climatic favorability classes for the grapevine downy mildew (Plasmopara viticola) during the years of the climate normal (1961-1990) and future climates (2011-2040, 2041-2070, and 2071$2100)$ in the B1 (A) and A2 (B) scenarios in Brazil.
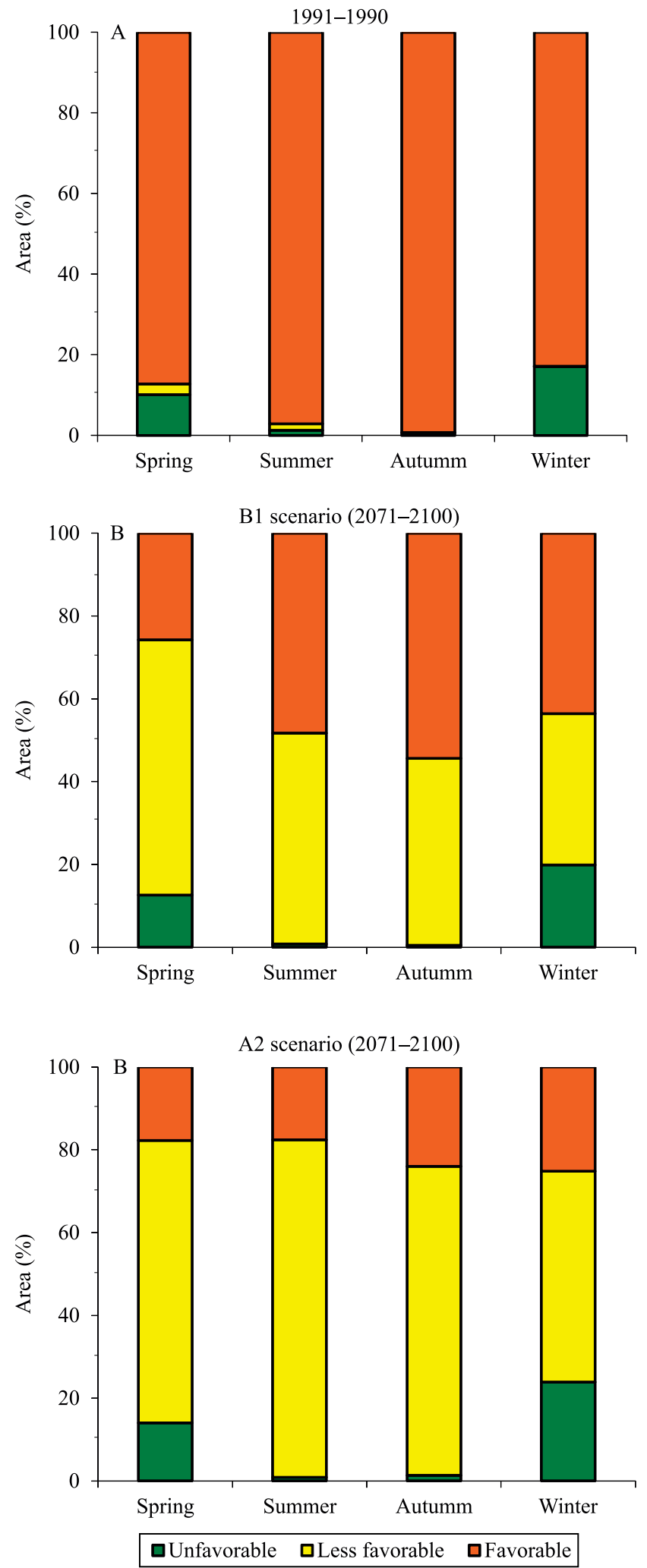

Figure 6. Percentage of favorability classes of grapevine downy mildew for the seasons of the year, during the climate normal (1961-1990) (A); the B1 scenario (2071-2100) (B); and the A2 scenario (2071-2100) (C). 
area for the two evaluated scenarios, B1 and A2. In general, the air temperature may be the most important factor in limiting pathogen development in autumn and winter, while humidity plays an important role in spring and summer (Siebold \& Tiedemann, 2012).

Under controlled conditions, the results allowed aggregating information and supporting the validation of the geographic and temporal distribution map of grapevine downy mildew. However, information on the metabolism, development, and morphology of the host plant, as well as variations in precipitation, could further contribute to the assessment of the impacts of climate change on disease development. This is due to the fact that there are reports of pathogen adaptation to new hosts and regarding the interference of temperature in genes of host resistance and pathogen virulence (Webb et al., 2010; Pangga et al., 2011). Thus, adaptation of pathogens and plants in response to temperature changes will remain a challenge for the research.

\section{Conclusions}

1. The grapevine downy mildew (Plasmopara viticola) severity is reduced when the air temperature increases.

2. In the projected scenario of climate change, it is possible to observe increased downy mildew favorability in the producing regions of the states of Rio Grande do Sul and Santa Catarina, reduction of favorability for the Submédio do Vale do São Francisco, and the maintenance of the conditions for the northern state of Paraná and eastern state of São Paulo.

3. The different Brazilian regions with vine cultivation show variability regarding the impacts of climate change on downy mildew.

\section{Acknowledgments}

To Fundação de Amparo à Ciência e Tecnologia de Pernambuco (Facepe) - a foundation for science and technology support of the state of Pernambuco - and to the Empresa Brasileira de Pesquisa Agropecuária (Embrapa), for the financial support.

\section{References}

AMBRIZZI, T.; ARAÚJO, M. (Coord.). Sumário executivo: base científica das mudanças climáticas. Rio de Janeiro: Painel Brasileiro de Mudanças Climáticas, 2013. 23p.
BUFFARA, C.R.S.; ANGELOTTI, F.; VIEIRA, R.A.; BOGO, A.; TESSMANN, D.J.; BEM, B.P. de. Elaboration and validation of a diagrammatic scale to assess downy downy mildew severity in grapevine. Ciência Rural, v.44, p.1384-1391, 2014. DOI: 10.1590/0103-8478cr20131548.

CAFFI, T.; LEGLER, S.E.; GONZÁLEZ-DOMÍNGUEZ, E.; ROSSI, V. Effect of temperature and wetness duration on infection by Plasmopara viticola and on post-inoculation efficacy of copper. European Journal of Plant Pathology, v.144, p.737-750, 2016. DOI: $10.1007 / \mathrm{s} 10658-015-0802-9$.

CHAKRABORTY, S.; NEWTON, A.C. Climate change, plant diseases and food security: an overview. Plant Pathology, v.60, p.2-14, 2011. DOI: 10.1111/j.1365-3059.2010.02411.x.

CLIMATIC RESEARCH UNIT. Available at: < http://www.cru. uea.ac.uk/>. Accessed on: Apr. 142016.

GHINI, R.; HAMADA, E.; ANGELOTTI, F.; COSTA, L.B.; BETTIOL, W. Research approaches, adaptation strategies, and knowledge gaps concerning the impacts of climate change on plant diseases. Tropical Plant Pathology, v.37, p.5-24, 2012. DOI: $10.1590 /$ S1982-56762012000100002.

HAMADA, E.; GHINI, R.; GONÇALVES, R.R. do V. Efeito da mudança climática sobre problemas fitossanitários de plantas: metodologia de elaboração de mapas. Engenharia Ambiental, v.3, p.73-85, 2006.

IPCC. Intergovernmental Panel on Climate Change. Data Distribution Centre. 2016. Available at: $<$ http://www.ipcc-data. org/>. Accessed on: Apr. 142016.

KENNELLY, M.M.; GADOURY, D.M.; WILCOX, W.F.; MAGAREY, P.A.; SEEM, R.C. Primary infection, lesion productivity, and survival of sporangia in the grapevine downy downy mildew pathogen Plasmopara viticola. Phytopathology, v.97, p.512-522, 2007. DOI: 10.1094/PHYTO-97-4-0512.

LALANCETTE, N.; MADDEN, L.V.; ELLIS, M.A. A quantitative model for describing the sporulation of Plasmopara viticola on grape leaves. Phytopathology, v.78, p.1316-1321, 1988. DOI: 10.1094/Phyto-78-1316.

MCELRONE, A.J.; HAMILTON, J.G.; KRAFNICK, A.J.; ALDEA, M.; KNEPP, R.G.; DELUCIA, E.H. Combined effects of elevated $\mathrm{CO}_{2}$ and natural climatic variation on leaf spot diseases of redbud and sweetgum trees. Environmental Pollution, v.158, p.108-114, 2010. DOI: 10.1016/j.envpol.2009.07.029.

PANGGA, I. B.; HANAN, J.; CHAKRABORTY, S. Pathogen dynamics in a crop canopy and their evolution under changing climate. Plant Pathology, v.60, p.70-81, 2011. DOI: 10.1111/j.13653059.2010.02408.x.

PUGLIESE, M.; GULLINO, M.L.; GARIBALDI, A. Effects of elevated $\mathrm{CO}_{2}$ and temperature on interactions of grapevine and powdery downy mildew: first results under phytotron conditions. Journal of Plant Diseases and Protection, v.117, p.9-14, 2010. DOI: $10.1007 / \mathrm{BF} 03356341$.

ROSSI, V.; CAFFI, T.; GIOSUÈ, S.; BUGIANI, R. A mechanist model simulating primary infections of downy downy mildew in grapevine. Ecological Modelling, v.212, p.480-449, 2008. DOI: 10.1016/j.ecolmodel.2007.10.046. 
SALINARI, F.; GIOSUÈ, S.; ROSSI, V.; TUBIELLO, F.N.; ROSENZWEIG, C.; GULlinO, M.L. Downy downy mildew outbreaks on grapevine under climate change: elaboration and application of an empirical-statistical model. EPPO Bulletin, v.37, p.317-326, 2007. DOI: 10.1111/j.1365-2338.2007.01126.x.

SALINARI, F.; GIOSUÈ, S.; TUBIELLO, F.N.; RETTORI, A.; ROSSI, V.; SPANNA, V.; ROSENZWEIG, C.; LODOVICA, G.M. Downy downy mildew (Plasmopara viticola) epidemics on grapevine under climate change. Global Change Biology, v.12, p.1299-1307, 2006. DOI: 10.1111/j.1365-2486.2006.01175.x.

SCHMIDT, C.; GÖRTZ, A.; BIELER, E.; THOMANN, R.; KASSEMEYER, H.-H. Downy downy mildew (Plasmopara viticola) - mechanisms of pathogenicity. Phytomedizin, v.42, p.1-3, 2012.

SHAW, M.W.; OSBORNE, T.M. Geographic distribution of plant pathogens in response to climate change. Plant Pathology, v.60, p.31-43, 2011. DOI: 10.1111/j.1365-3059.2010.02407.x.

SIEBOLD, M.; TIEDEMANN, A. von. Potential effects of global warming on oilseed rape pathogens in Northern Germany. Fungal Ecology, v.5, p.62-72, 2012. DOI: 10.1016/j.funeco.2011.04.003.

SOLOMON, S.; QIN, D.; MANNING, M.; CHEN, Z.; MARQUIS, M.; AVERYT, K.B.; TIGNOR, M.; MILLER, H.L.
(Ed.). Climate change 2007: the physical science basis: summary for policymakers. Cambridge: Cambridge University, 2007. 18p. Contribution of Working Group I to the Fourth Assessment Report of the Intergovernmental Panel on Climate Change. Available at: $<$ https://www.ipcc.ch/pdf/assessment-report/ar4/wg1/ar4-wg1spm.pdf $>$. Accessed on: Apr. 142016.

STOCKER, T.F.; QIN, D.; PLATTNER, G.-K.; TIGNOR, M.M.B.; ALLEN, S.K.; BOSCHUNG, J.; NAUELS, A.; XIA, Y.; BEX, V.; MIDGLEY, P.M. (Ed.). Climate change 2013: the physical science basis: summary for policymakers. Cambridge: Cambridge University, 2013. 33p. Working Group I Contribution to the Fifth Assessment Report of the Intergovernmental Panel on Climate Change. Available at: <https:/www.ipcc.ch/pdf/ assessment-report/ar5/wg1/WGIAR5_SPM_brochure_en.pdf $>$. Accessed on: Apr. 142016.

TETENS, V.O. Uber einige meteorologische begriffe. Zeitschrift fur Geophysik, v.6, p.297-309, 1930.

WEBB, K.M.; OÑA, I.; BAI, J.; GARRETT, K.A.; MEW, T.; VERA CRUZ, C.M.; LEACH, J.E. A benefit of high temperature: increased effectiveness of a rice bacterial blight disease resistance gene. New Phytologist, v.185, p.568-576, 2010. DOI: 10.1111/j.1469-8137.2009.03076.x.

Received on July 20, 2016 and accepted on October 5, 2016 